\title{
IMPACT OF IMPLEMENTATION OF IFRS 9 ON CZECH BANKING SECTOR*
}

\section{Ol'ga Pastiranováa , Jiří Witzanyª}

\begin{abstract}
The aim of this study is to provide an overview of the principles of IFRS 9 implementation and to analyse its impact on the Czech banking sector. Unlike the previous IAS 39 standard, valid until the end of 2017, the new accounting rules require banks to estimate forward-looking expected credit losses (ECL) while considering relevant exposure level information as well as available macroeconomic predictions. Due to the increased complexity of the ECL models and changing macroeconomic expectations, we hypothesize that the new standard leads to increased volatility of loan loss allowances. This hypothesis is empirically tested and more or less confirmed by an analysis of the quarterly flows of allowances for a sample of large Czech banks from the years 2016-2017 under IAS 39 and from 2018-2019 under IFRS 9.
\end{abstract}

Keywords: IFRS 9, banks, expected credit loss, loan loss allowances

JEL Classification: G21, G12, G32

\section{Introduction}

The new IFRS 9 Financial Instruments (IASB, 2014) accounting standard became effective on 1 January 2018, and its use is mandatory for all institutions using the IFRS accounting standards. The main motivation behind the introduction of the new standard was to upgrade the rules for the creation of allowances set by the IAS 39 (IASB, 2003) standard, which are based on the recognition of allowances after the moment of default of a financial asset. This ex-post recognition of impairment has been generally considered "too little too late". Moreover, the rules are considered procyclical - stimulating the provision of loans during times of economic booms and, subsequently, tightening the conditions for loan provision

* $\quad$ This paper has been written with the financial support of grants entitled "Development Trends on Financial Markets" IG102029 and GAČR 18-05244S "Innovation Approaches to Credit Risk Management", which the authors gratefully acknowledge.

a Faculty of Finance and Accounting, Prague University of Economics and Business, Prague, Czech Republic

Emails: olga.pastiranova@vse.cz,jiri.witzany@vse.cz 
and a rapid increase in the creation of allowances for impaired loans by banks during an economic recession, which only worsens the impact of recession. Beatty and Liao (2011) observed that delays in the creation of allowances increase the negative impact of an economic recession on loans provided by banks. Additionally, a negative relationship between the recognition of allowances and GDP growth, accompanied by an increased volume of loans provided, has been observed (Leaven and Majnoni, 2003; Beerbaum, 2015). A discussion has been fuelled regarding the procyclical effect of the accounting rules. For example, Amel-Zadeh et al. (2017) argue that the procyclical effect may be an outcome of weak banking supervision, and not necessarily of fair value accounting principles. In their empirical study, Bikker and Metzemakers (2005) note that the strong procyclical effect is partially mitigated by the positive impact of earnings on allowances. Nevertheless, based on the experience of the latest recession in 2008 and the subsequent requirements for improvement to the rules for the creation of loan loss allowances, the International Accounting Standards Board published the final version of the IFRS 9 Financial Instruments (hereinafter referred to as "IFRS 9") standard, replacing IAS 39 Financial Instruments: Recognition and Measurement (hereinafter referred to as "IAS 39").

IFRS 9 requires the creation of allowances using forward-looking information and, thus, the recognition of expected credit losses (hereinafter referred to as "ECL"), replacing the model of incurred credit losses (BCBS, 2015; Bischof and Daske, 2016). The rules are therefore believed to have an anticyclical effect. On the other hand, the new standard challenges banks with the need to develop relatively sophisticated new ECL models incorporating all available exposure level information as well as macroeconomic predictions. The complexity of the models, which often depend on noisy datasets and uncertain predictions, might lead to higher volatility of bad debt expenses and thus to lower stability of banks' financial results. According to the results of Polák and Panoš (2019), macroeconomic expectations play a crucial role in the pass-through of impairment. An existing analysis of the impact of IFRS 9 on the Czech banking sector shows that the implementation of the of new standard led to a decrease in the value of financial assets in Czech banks by approximately $0.8 \%$ comparing the end of 2017 and the end of 2018 (Lukeš, 2019).

The aim of this study is to provide an overview of the impacts of the implementation of IFRS 9 on the Czech banking sector two years after its adoption, with a focus on the volatility of loan loss allowances, and to depict their development throughout 2016-2017 and 2018-2019. In the first part, the study summarizes the main principles of the new standard related to the impairment rules, and highlights the differences compared to IAS 39. The next section introduces the Czech banking sector, represented by a selected bank sample, and discusses our hypothesis about the increased volatility of allowances under IFRS 9. The last section presents the results of our qualitative and quantitative 
analysis. We summarize the main methodological choices taken by the selected banks and then focus on the main loan portfolio quality indicators related to the implementation of the new standard, in particular on the development of allowance flows and their volatility, in order to test our hypothesis.

\section{IFRS 9 Impairment Requirements}

The new standard requires banks to categorize financial assets into one of three stages and to estimate ECL depending on the debtor credit risk level as follows:

- Stage 1: For low credit risk exposures [IFRS 9, 5.5.5] banks report only 12-month ECL, defined as the portion of lifetime expected credit losses that represent the expected credit losses that result from default events on a financial asset that are possible within the 12 months after the reporting date [IFRS 9, Appendix A]. The allowance corresponding to 12-month ECL is applied at the moment of the first recognition of the financial asset (for example, the moment a loan is granted). The interest revenue is based on the effective interest rate applied to the gross carrying amount of the asset.

- Stage 2: In the case of a significant increase in credit risk, IFRS 9 requires recognition of lifetime ECL, defined as the expected credit losses that result from a possible default event that may take place during the expected life of a financial asset [IFRS 9, Appendix A]. Such a financial asset belongs to Stage 2. The interest revenue is still calculated based on the effective interest rate applied to the gross carrying amount of the asset as in the first stage.

- Stage 3: A financial asset should be categorized into Stage 3 in the case of default, when it is not probable that the receivable will be repaid in full. In this case, banks recognize lifetime ECL, as in the second stage. The interest revenue is calculated based on the effective interest rate applied to the net carrying amount (gross carrying amount minus loss allowance).

The 12-month and lifetime ECL can be estimated using different models. The most standard approach is to decompose the 12-month ECL into a product of the probability of default (PD), loss given default (LGD), and exposure at default (EAD):

$$
E C L_{12 M}=P D \times L G D \times E A D .
$$

In the case of Stage 2 lifetime ECL, banks need to estimate not only the probability of default over the first year of the loan $\left(P D_{1}\right)$ but also that over the second year of the loan $\left(P D_{2}\right)$, etc. The lifetime ECL (see Witzany, 2017) can be expressed as: 


$$
E C L_{\text {lifetime }}=\sum_{i=1}^{n} P D_{i} \times L G D_{i} \times E A D_{i},
$$

where $L G D_{i}$ denotes the loss given default in the year $i, E A D_{i}$ the exposure at default in the year $i$, and $n$ the maturity of the exposure. For Stage 3 exposures, the default has already taken place, so there is no need to estimate the probability of default. In this case, the lifetime ECL is estimated based on the forward-looking recovery rates or expected cash flows.

There are several methodological approaches that can be employed to estimate the lifetime probabilities of default (see, e.g., Miu and Ozdemir, 2017). The most popular one is based on rating transition matrices and the Markov chain model. The bank estimates a through-the-cycle (TTC) matrix based on its historical data recording migrations between the internal rating grades (including the state of default). The TTC transition matrix is then adjusted, conditional on a macroeconomic scenario. The cumulative and marginal (yearly) probabilities of default can be obtained by matrix multiplication. The adjustment of the matrices presents a modelling challenge involving the development of a model linking macroeconomic data to past probabilities of default. In addition, the banks need to consider not only one expected baseline economic scenario, but also at least two more, optimistic and adverse, with appropriate probability weights. Another modelling approach uses the concept of survival modelling, where the cumulative probabilities of default are directly expressed by a regression model that should include not only exposure specifics, but also macroeconomic factors.

An essential element of an ECL model is the definition of a reclassification between Stages 1 and 2, which is triggered by a "significant increase in credit risk", which is not defined precisely by the standard. It means that banks must implement their own approach to the definition of a "significant increase in credit risk". IFRS 9 states that the assessment of such an increase should be based on information which is rational and verifiable, forward-looking, and available without undue cost and effort [IFRS 9, 5.2.2.1]. Banks should assess the relative and absolute change in PD between the initial recognition of the financial asset and the reporting date as a primary indicator. The standard states that the rebuttable assumption that significant increase in credit risk occurs when the contractual payments (for example repayment of principal or interest) become more than 30 days due [IFRS 9, 5.2.2.8]. However, the standard assumes that the banks will assess other information as well, such as detailed quantitative information on the actual probability of default, external or internal rating, financial situation, or qualitative information regarding the borrower's legal and economic situation (Poole et al., 2016). 
The key differences in comparison with the impairment model according to IAS 39 are as follows:

- Recognition of loan loss allowances according to the expected credit losses. Under IAS 39, loan loss allowances were recognized only in the case of evidence of impairment of financial assets and after proof that such impairment existed. IFRS 9, by contrast, requires earlier recognition of credit losses which are expected to occur, without their evidence, expressed as 12-month ECL in Stage 1, or lifetime ECL in Stages 2 and 3 in the case of expected significant deterioration of the instrument credit quality.

- Use of forward-looking information. While IAS 39 relied only on historical information for the assessment of impairment, in order to recognize the expected credit losses, financial institutions must now include forward-looking information, including forecasts of future macroeconomic conditions, in the calculation of ECL.

The summary above shows that the ECL impairment models must contain a number of relatively more sophisticated modelling steps compared to the IAS 39 approach. The ECL estimates depend on macroeconomic predictions, which may change from optimistic to pessimistic. Swings in the market mood may have a significant impact especially on lifetime ECL. In addition, ECL models linking macroeconomic indicators to probabilities of default need to be developed on relatively large datasets, which introduces additional model and data noise into the results. Therefore, we expect that the implementation of IFRS 9 will cause increased volatility of loan loss allowances, which implies increased volatility of results of financial institutions due to the recognition of allowances through profit and loss.

\section{Data and Methodology}

In order to identify the impact of the IFRS 9 implementation on the Czech banking sector, we are first going to introduce this sector in terms of its size and volume. The total balance sheet of the banking sector in the Czech Republic as of 31 December 2019 was 7.5 trillion CZK, out of which 6 trillion CZK (80\%) was composed of loan receivables. At the end of 2019, there were 49 financial institutions with a bank license (ČNB, 2020), consisting of banks and branches of foreign banks, while the balance sheets of the nine biggest banks represented $79 \%$ of the total balance sheet of the whole banking sector. The above-mentioned institutions, which are representative of the whole banking sector for the purposes of this article, were selected based on their balance sheets, with the threshold set at a minimum of 140 billion CZK. Table 1 presents the sample of the nine biggest banks as of 31 December 2019 according to their consolidated balance sheets. 
Table 1: List of largest banks in Czech Republic as of 31 Dec 2019 according to balance sheet

\begin{tabular}{l|c|c|c|c}
\hline Bank & $\begin{array}{c}\text { Balance } \\
\text { sheet } \\
\text { (million CZK) }\end{array}$ & $\begin{array}{c}\text { Loan } \\
\text { portfolio } \\
\text { (million CZK) }\end{array}$ & $\begin{array}{c}\text { Allowances } \\
\text { (million } \\
\text { CZK) }\end{array}$ & $\begin{array}{c}\text { Proportion } \\
\text { in banking sector } \\
\text { balance sheet (\%) }\end{array}$ \\
\hline Česká spořitelna, a.s. (CS) & $1,458,650$ & 720,739 & 12,640 & 19 \\
\hline $\begin{array}{l}\text { Československá obchodní } \\
\text { banka, a.s. (CSOB) }\end{array}$ & $1,631,067$ & 849,091 & 7,483 & 22 \\
\hline Fio banka, a.s. (FIO) & 146,770 & 15,688 & 861 & 2 \\
\hline J\&T BANKA, a.s. (J\&T) & 151,722 & 68,320 & 3,448 & 2 \\
\hline Komerční banka, a.s. (KB) & $1,077,334$ & 647,258 & 8,921 & 14 \\
\hline $\begin{array}{l}\text { MONETA Money Bank, a.s. } \\
\text { (MMB) }\end{array}$ & 219,053 & 156,409 & 2,674 & 3 \\
\hline PPF banka a.s. (PPF) & 226,774 & 21,798 & 1,085 & 3 \\
\hline Raiffeisenbank a.s. (RB) & 372,225 & 221,877 & 4,420 & 5 \\
\hline UniCredit Bank Czech Republic & 686,593 & 391,509 & 9,993 & 9 \\
\hline and Slovakia, a.s. (UNI) & & & & \\
\hline
\end{tabular}

Source: Authors, data extracted from banks' annual reports and quarterly reporting

The analysis presented in the following sections provides an overview of the most important qualitative and quantitative impacts of the IFRS 9 that the Czech banking sector was facing prior to its implementation and during the first years after its adoption. All the financial and non-financial data are extracted from the banks' official sources, mostly from the annual reports and quarterly reporting available on their web sites, and from the official statistical data of the Czech National Bank (ČNB, 2020). The qualitative impacts are analysed descriptively, while for quantitative impacts we focus on the development of loan loss allowances. The following hypothesis is statistically tested: "The implementation of IFRS 9 has increased the volatility of net loan loss allowances with an immediate impact on banks' results."

\section{Qualitative Impacts on Czech Banking Sector}

The Czech banks have had to invest considerable human and financial resources to implement the new processes and models required by the new IFRS 9 accounting standard.

The development and implementation of models for the calculation of ECL has been one of the greatest challenges for all the banks. Most of them have adopted the model 
internally within their bank group. For non-performing (Stage 3) exposures, banks mostly calculate individual allowances using the discounted cash flow method. Proposed allowances are usually subject to the approval of a credit committee or approval at group level. For performing exposures (Stages 1 and 2), banks need to estimate PD, LGD, and EAD parameters, usually by applying advanced statistical models.

Regarding the categorization of receivables, until the end of 2017, Czech banks classified loan receivables into one of two following categories and five sub-categories, according to Regulation no. 163/2014 Coll., Sections 80 to 82 (ČNB, 2014):

- receivables without debtor default: standard receivables, watch receivables;

- receivables with debtor default: non-standard, doubtful and loss receivables.

A basic criterion for the assessment of decrease in the value of receivables based on the above-mentioned regulation was the number of days past the due date of payments of principal and interest, and the deterioration in the debtor's financial situation. Both criteria were assessed ex-post, using available historical information.

In compliance with IFRS 9, there is an amendment to the Regulation, including a change in the above-mentioned categorization of loan receivables in Section 80 into two categories instead of five, as follows:

- $\quad$ performing exposures: receivables in Stage 1 and Stage 2;

- $\quad$ non-performing exposures: receivables in Stage 3.

The classification of loan receivables should be consistent with the new standard, so that performing exposures represent receivables categorized in Stage 1 and Stage 2 (debtors without default) and non-performing exposures represent receivables in Stage 3 (debtors in default).

All the banks in the sample have adopted the above-mentioned categorization of receivables. Additionally, some of the banks use other sub-categories, such as client type, region or industry branch.

According to recently introduced regulations, banks need to evaluate whether, at the reporting date, there has been a significant increase in credit risk since the initial recognition of a financial asset, as its occurrence triggers reclassification of a loan receivable from Stage 1 to Stage 2 and recognition of lifetime ECL instead of 12-month ECL. It is the responsibility of the banks, as a part of their internal processes, to define exactly what "significant increase in credit risk" means. However, this should be based on both qualitative and quantitative indicators, while the main indicator should be relative and absolute change in the probability of the debtor's default. Table 2 presents an overview of the criteria indicating a significant increase in credit risk adopted by the banks in our sample. 
Table 2: Assessment of significant increase in credit risk

\begin{tabular}{|c|c|}
\hline Bank & Assessment of significant increase in credit risk \\
\hline CS & $\begin{array}{l}\text { - qualitative criteria: information about forbearance, restructuring, fraudulent behaviour } \\
\text { - quantitative criteria: changes in PD exceeding absolute and relative threshold }\end{array}$ \\
\hline CSOB & $\begin{array}{l}\text { - internal rating as the main indicator } \\
\text { - comparison of PD at initial recognition with PD at reporting date, behavioural score, } \\
30 \text { days past due, management evaluation, forbearance }\end{array}$ \\
\hline FIO & - contractual payments more than 30 days past due \\
\hline J\&T & $\begin{array}{l}\text { - quantitative factors: change in internal rating since initial recognition - exceeding } \\
\text { the threshold for PD (three times higher mean value of PD given by the rating class) } \\
\text { - qualitative factors: expectation of sale of exposure with significant losses related to credit } \\
\text { quality, change of project with negative impact on debtor's ability to generate positive } \\
\text { cash flows, debtor has not fulfilled non-financial contractual obligations for more than six } \\
\text { months }\end{array}$ \\
\hline KB & $\begin{array}{l}\text { - relative and absolute criteria such as contractual payments more than } 30 \text { days past due, } \\
\text { deterioration of debtor's financial situation, } 24 \text {-month trial period after restructuring }\end{array}$ \\
\hline MMB & $\begin{array}{l}\text { - contractual payments more than } 30 \text { days past due or similar qualitative criteria indicating } \\
\text { increase in credit risk; comparison of PD at initial recognition with PD at reporting date - } \\
\text { change exceeding relative and absolute threshold }\end{array}$ \\
\hline PPF & - contractual payments more than 30 days past due \\
\hline RB & $\begin{array}{l}\text { - quantitative as primary indicator: increase in PD (comparison of lifetime PD at initial } \\
\text { recognition with lifetime PD at reporting date), contractual payments more than } 30 \text { days } \\
\text { past due } \\
\text { - qualitative as secondary indicator: external market indicators, change in contractual } \\
\text { conditions, change in management, expert judgement for non-retail portfolios updated } \\
\text { quarterly, relief provided to client in economic difficulties, expert judgement on retail } \\
\text { portfolios updated monthly }\end{array}$ \\
\hline UNI & $\begin{array}{l}\text { - combination of relative and absolute factors such as relative change in PD at initial } \\
\text { recognition and PD at reporting date, contractual payments more than } 30 \text { days past due, } \\
\text { forbearance status }\end{array}$ \\
\hline
\end{tabular}

Source: Authors, data extracted from banks' annual reports

The table confirms that Czech banks use both qualitative and quantitative criteria to assess a significant increase in credit risk as indicated above. Among the most common criteria are the relative and absolute threshold for change in PD since initial recognition, contractual payments more than 30 days past due and the forbearance status of a receivable.

Banks also need to assess the default of a receivable, as it triggers reclassification of the asset from Stage 2 to Stage 3. In this case, there is no change in the ECL concept, as lifetime ECL applies to both stages. Table 3 presents the criteria indicating default adopted by the banks in the sample. 
Table 3: Assessment of default

\begin{tabular}{|c|c|}
\hline Bank & Assessment of default \\
\hline CS & - not specified \\
\hline CSOB & $\begin{array}{l}\text { - significant deterioration in debtor's creditworthiness, forbearance status of receivable, } \\
\text { bankruptcy, client has stopped drawing on the loan, contractual payments more than } 90 \\
\text { days past due as an ultimate indicator }\end{array}$ \\
\hline FIO & - contractual payments more than 90 days past due \\
\hline J\&T & $\begin{array}{l}\text { - liquidation or bankruptcy, contractual payments more than } 90 \text { days past due, restructuring } \\
\text { of receivable, } 20 \% \text { of provided financing used for a purpose other than that determined } \\
\text { by the agreement }\end{array}$ \\
\hline KB & $\begin{array}{l}\text { - debtor having significant financial problems, breach of contractual conditions such } \\
\text { as contractual payments more than } 90 \text { days past due, increased probability of client's } \\
\text { bankruptcy, active market for the asset ceases to exist due to financial problems, special } \\
\text { relief from creditors' side }\end{array}$ \\
\hline MMB & $\begin{array}{l}\text { - significant part of the debtor's principal, interest or fees are more than } 90 \text { days past due, } \\
\text { within past } 6 \text { months bank has provided relief for any part of debtor's exposure due } \\
\text { to deterioration of his financial situation, internal client rating OR22 (PD 100\%), bankruptcy }\end{array}$ \\
\hline PPF & $\begin{array}{l}\text { - contractual payments more than } 90 \text { days past due, restructuring of the receivable, } \\
\text { bankruptcy, debtor does not generate enough income to repay the debt, breach } \\
\text { of covenants, active market for the asset ceases to exist due to debtor's financial problems }\end{array}$ \\
\hline RB & $\begin{array}{l}\text { - contractual payments more than } 90 \text { days past due, receivable is not accrued due } \\
\text { to deterioration of the debtor's financial situation, receivable sold with significant loss, } \\
\text { restructuring, debtor is bankrupt, has committed loan fraud or is dead, loan agreement } \\
\text { terminated early because debtor did not fulfil contractual conditions }\end{array}$ \\
\hline UNI & - not specified \\
\hline
\end{tabular}

Source: Authors, data extracted from banks' annual reports

As is obvious from the table, the most common indicators of the debtor's default are bankruptcy or liquidation, contractual payments more than 90 days past due and deterioration of the debtor's financial situation.

To calculate the potential expected credit losses (ECL) arising from exposures, banks need not only to evaluate historical information but also to include a forecast estimation of the development of key macroeconomic indicators in various scenarios (forward-looking information). Banks may use external sources (e.g., the Czech National Bank or Czech Statistical Office) or forecast the development internally using their own models. Most banks in the sample use indicator development data which result from their internal models. Table 4 summarizes the macroeconomic indicators used by the banks in the sample. 
Table 4: Forward-looking information used in models

\begin{tabular}{|c|c|}
\hline Bank & Forward-looking information used in models \\
\hline CS & $\begin{array}{l}\text { - forward-looking information representing deviations from a default forecast scenario, } \\
\text { determined internally by the bank group research and development department } \\
\text { - estimated macroeconomic variables: gross domestic product, unemployment rate, } \\
\text { inflation rate, market interest rates; however, GDP is considered to be the main indicator }\end{array}$ \\
\hline CSOB & $\begin{array}{l}\text { - three forward-looking macroeconomic scenarios with different weights, while the basic } \\
\text { macroeconomic scenario is represented by estimation of the most probable result } \\
\text { - prediction of variables used in scenarios are provided by the main group economist } \\
\text { on a quarterly basis } \\
\text { - main macroeconomic indicators: gross domestic product growth rate, unemployment } \\
\text { rate, interbank interest rate, exchange rate, government bond yield, real estate prices, } \\
\text { inflation rate }\end{array}$ \\
\hline FIO & - not specified \\
\hline J\&T & - not specified \\
\hline KB & - not specified \\
\hline Ммв & - not specified \\
\hline PPF & - not specified \\
\hline RB & $\begin{array}{l}\text { - key economic indicators defined by the group: gross domestic product, unemployment } \\
\text { rate (for all portfolios), long-term yield on government bonds (especially for non-retail } \\
\text { portfolios), inflation rate, real estate prices (especially for retail portfolios) } \\
\text { - all indicators estimated in three scenarios with weights attached to each scenario } \\
\text { as follows: optimistic weight } 25 \% \text {, basic weight } 50 \% \text {, pessimistic weight } 25 \% \text { ) } \\
\text { - scenarios estimated internally by Raiffeisen Research department } \\
\text { - additional use of expert judgement if needed }\end{array}$ \\
\hline UNI & - not specified \\
\hline
\end{tabular}

Source: Authors, data extracted from banks' annual reports

The most common macroeconomic indicators used in the ECL models are GDP growth, unemployment rate, short-term or long-term interest rates and government bond yield. The macroeconomic scenarios are usually estimated internally with different probability weights, of which the baseline scenario is the most important one, while the others are alternative, including an optimistic and an adverse scenario. Even though some banks do not publish the types of macroeconomic indicators included in the models, we expect that they do not differ significantly from those reported in Table 4. Some banks differentiate their indicators used for retail and non-retail portfolios. Banks also tend to include expert judgement to support their forecast scenarios. Banks do not report significant problems with including forward-looking information in the models, 
but they might have various econometric weaknesses, for example low explanatory power of the macroeconomic indicators due to the probability of default introducing an estimation error into the predictions.

Finally, regular validation and back-testing, or, more precisely, estimation accuracy evaluation, modification and calibration, are part of each model development and implementation process. Regular validation of a new model is of key importance for adequacy of the internal processes and trustworthiness of the reported information of each bank. All the banks perform back-testing on a regular basis, at least once a year, or ad hoc when needed.

\section{Quantitative Impacts on Czech Banking Sector}

Due to the change in rules for the creation of loan loss allowances, the implementation of the new standard has a direct impact on the volume and flow of allowances, and on the banks' profit and loss. The following text aims to analyse the impact of the implementation of IFRS 9 on the volatility of the loan loss allowances of the banks in the sample.

\subsection{Loan loss allowances according to new standard}

All financial institutions in the sample reported loan loss allowances according to the new methodology as of 1 January 2018, while financials from 31 December 2017 remained reported under the IAS 39 methodology. Allowances under IFRS 9 are expected to increase compared to IAS 39 due to the creation of Stage 1 and 2 allowances for performing receivables. The differences resulting from the adoption of IFRS 9 were reported in balances as of 1 January 2018. The changes in allowances between 31 December 2017 and 1 January 2018 are therefore solely a result of the reclassification and revaluation of financial assets due to the new methodology, while changes between 1 January 2018 and 31 December 2018 are both the result of reclassification and revaluation due to IFRS 9 and development in the portfolio credit quality. If the impact of the new standard between the end of 2017 and the beginning of 2018 was negative, it must have been absorbed by the bank's capital. Table 5 presents the development of the yearly cost of risk of the banks in the sample in the period 2016-2019 and the stock of allowances between 31 December 2017 and 1 January 2018. 
Table 5: Development of annual cost of risk in 2016-2019 (million CZK)

\begin{tabular}{l|c|c|c|c|c|c|c}
\hline Bank & $\begin{array}{c}\text { Cost } \\
\text { of risk } \\
\mathbf{2 0 1 6}\end{array}$ & $\begin{array}{c}\text { Cost } \\
\text { of risk } \\
\mathbf{2 0 1 7}\end{array}$ & $\begin{array}{c}\text { Allowances } \\
\mathbf{3 1} \text { Dec 2017 } \\
\text { (IAS 39) }\end{array}$ & $\begin{array}{c}\text { Allowances } \\
\text { 1 Jan 2018 } \\
\text { (IFRS 9) }\end{array}$ & $\begin{array}{c}\text { Change } \\
\text { (IAS 39 - } \\
\text { IFRS 9) in (\%) }\end{array}$ & $\begin{array}{c}\text { Cost } \\
\text { of risk } \\
\mathbf{2 0 1 8}\end{array}$ & $\begin{array}{c}\text { Cost } \\
\text { of risk } \\
\mathbf{2 0 1 9}\end{array}$ \\
\hline CS* & $-4,123$ & 518 & 12,399 & 13,905 & 12.1 & 2,482 & 778 \\
\hline CSOB* & -617 & -131 & 6,296 & 6,800 & 8.0 & -214 & -313 \\
\hline FIO** & -91 & 312 & 527 & 576 & 9.3 & -22 & 307 \\
\hline J\&** & $-2,076$ & $-1,004$ & 3,023 & 3,420 & 13.1 & -909 & 1,843 \\
\hline KB* & $-1,817$ & 387 & 12,757 & 13,592 & 6.5 & 643 & 571 \\
\hline MMB* & -870 & -381 & 4,062 & 4,738 & 16.6 & -274 & -517 \\
\hline PPF** & -11 & -30 & 1,067 & 1,218 & 14.2 & -150 & 283 \\
\hline RB** & 47 & 1,133 & 4,969 & 4,837 & -2.7 & -1 & 427 \\
\hline UNI** & 285 & 1,150 & 8,870 & 8,895 & 0.3 & -905 & -193 \\
\hline
\end{tabular}

Source: Authors' calculation, *based on consolidated data/**based on individual data (consolidated not available) extracted from banks' quarterly reporting (negative cost of risk indicates net creation of allowances, while a positive sign indicates a release of allowances)

The initial impact of the adoption of the new methodology was mostly negative, with an increase in allowances between the end of 2017 and the beginning of 2018 as much as $16.6 \%$ in the case of MMB (2020). RB (2020), on the other hand, reported a small decrease of allowances by $2.7 \%$, which can be explained by the release of large collective allowances under IAS 39 and/or by the new methodology for lifetime ECL of non-performing exposures. For UNI (2020), the initial impact of the new standard appears to be neutral, with only a negligible increase in allowances by $0.3 \%$. To test the hypothesis of increased volatility of allowances under IFRS 9, we are going to analyse the quarterly data.

Distribution of exposures among stages is a new quantitative impact of IFRS 9 implementation. This reflects the quality of the loan portfolio, but also the staging methodology defined by the banks. Figure 1 shows the staging distribution at the end of 2019 . 
Figure 1: Distribution of loan portfolios of banks among stages as of 31 Dec 2019

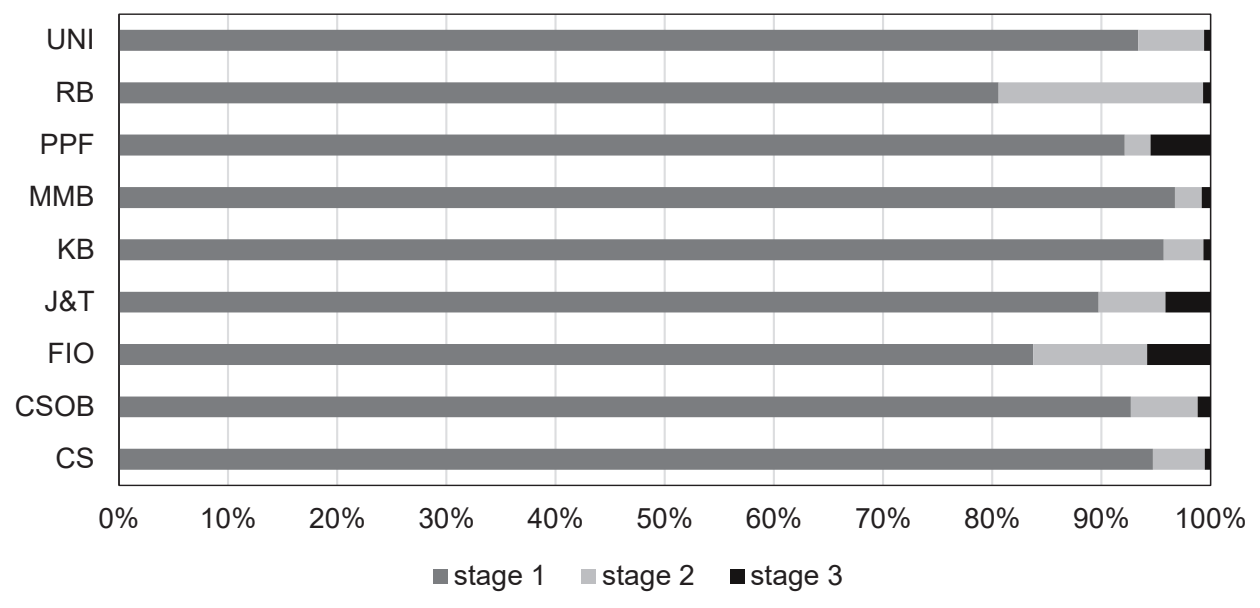

Source: Authors' calculation, data extracted from banks' annual reports

Most banks in the sample reported that more than $90 \%$ of their net loan receivables were classified in Stage 1, up to 6\% of net loan receivables in Stage 2, and 1\% of their portfolio comprised defaulted receivables. However, there are banks where the distribution of the loan portfolio differs from the overall average. For example, RB reported that $19 \%$ of its loan portfolio was in Stage 2 (significantly more than in other institutions). On the other hand, PPF (2020) and FIO (2020) reported 6\% of their loan portfolio in Stage 3, and J\&T reported 4\% of its portfolio in Stage 3. The smallest portfolio of receivables in Stage 2 is reported by MMB and PPF, representing only $2 \%$ of the whole portfolio, indicating, perhaps, that they have a narrower definition of Stage 2 receivables than other banks. Generally, based on the data above, we can conclude that there might be significant differences in Stage 2 definition. Nevertheless, on the whole, in view of the small proportion (around 1\%) of Stage 3 (i.e., non-performing receivables), the credit quality of the Czech banking sector appears to be relatively good.

\subsection{Volatility of loan loss allowances}

Loan loss allowances are inherently impacted by the new standard. All the financial institutions in the sample reported loan loss allowances according to the new methodology being used since 1 January 2018, while financials up until 31 December 2017 remained reported under IAS 39 methodology (which is allowed by the standard - there is 
an exemption from the requirement to restate the prior period). None of the banks in the sample adopted IFRS 9 before the effective date.

In order to analyse the development of loan loss allowances and test the hypothesis, data on quarterly volume and flows of loan loss allowances and loan portfolio balances of the banks in the sample for the period 2016-2019 were extracted from the banks' financial reports. The quarterly flows of allowances (costs of risk), which include the effect of write-offs and sales of receivables, were available for five of the banks. For the four banks where they were unavailable (FIO, PPF, RB and UNI), we used the quarterly change in the stock of allowances as an approximation of the flow. Such an approximation may have a potential downside as write-offs and sales of receivables for the respective period are not excluded and the stock of allowances might be impacted in the case of significant write-offs or sales of receivables. The cost of risk of the four banks mentioned above for 1Q 2018 was calculated as a deduction between allowances as of 31 March 2018 and restated allowances as of 1 January 2018.

The ratio of the quarterly flows of allowances to the loan portfolio balance at the beginning of the respective quarter (cost of risk) was calculated, which resulted in 16 observations for each bank. Figure 2 shows the development of the quarterly ratios in the period 2016-2019 for the nine banks in the sample.

The quarterly development of cost of risk for most banks visually seems to have been more volatile in 2018-2019 under IFRS 9 than in 2016-2017, when the IAS 39 standard was applied. This effect is not so obvious when we look at the development of the quarterly cost of risk in 2017 and 2018 across the nine banks (total flow of allowances divided by total loan portfolio balance at the beginning of the respective quarter) in Figure 3. In fact, the relatively large creation of allowances in 2016 followed by an overall release of allowances in 2017 (standard deviation of quarterly changes) caused the volatility in 2016-2017 to be larger than in 2018-2019. The scale ranges of changes in cost of risk are individual for each bank in the sample and therefore depict the development of cost of risk at the individual level, which does restrict us to observing the changes and their comparison among the banks.

It is interesting to note that some of the banks, in particular CS and $\mathrm{KB}$, were more or less regularly releasing allowances on a quarterly basis in 2018-2019. Furthermore, we can observe that CS and MMB released significant portions of allowances in 1Q 2018, explained by gains from collection of receivables in the segment of corporate and small business at CS and by gain from non-performing loan sales with a positive effect on cost of risk at MMB. On the other hand, some of the banks reported substantial losses in 1Q 2018, for example RB, where such losses were affected by continual release of allowances in previous quarters, followed by a significant release of allowances in 1Q 2019, due to improved portfolio in the household segment. 
Figure 2: Quarterly costs of risk in 2016-2019 for sample of banks (\%)

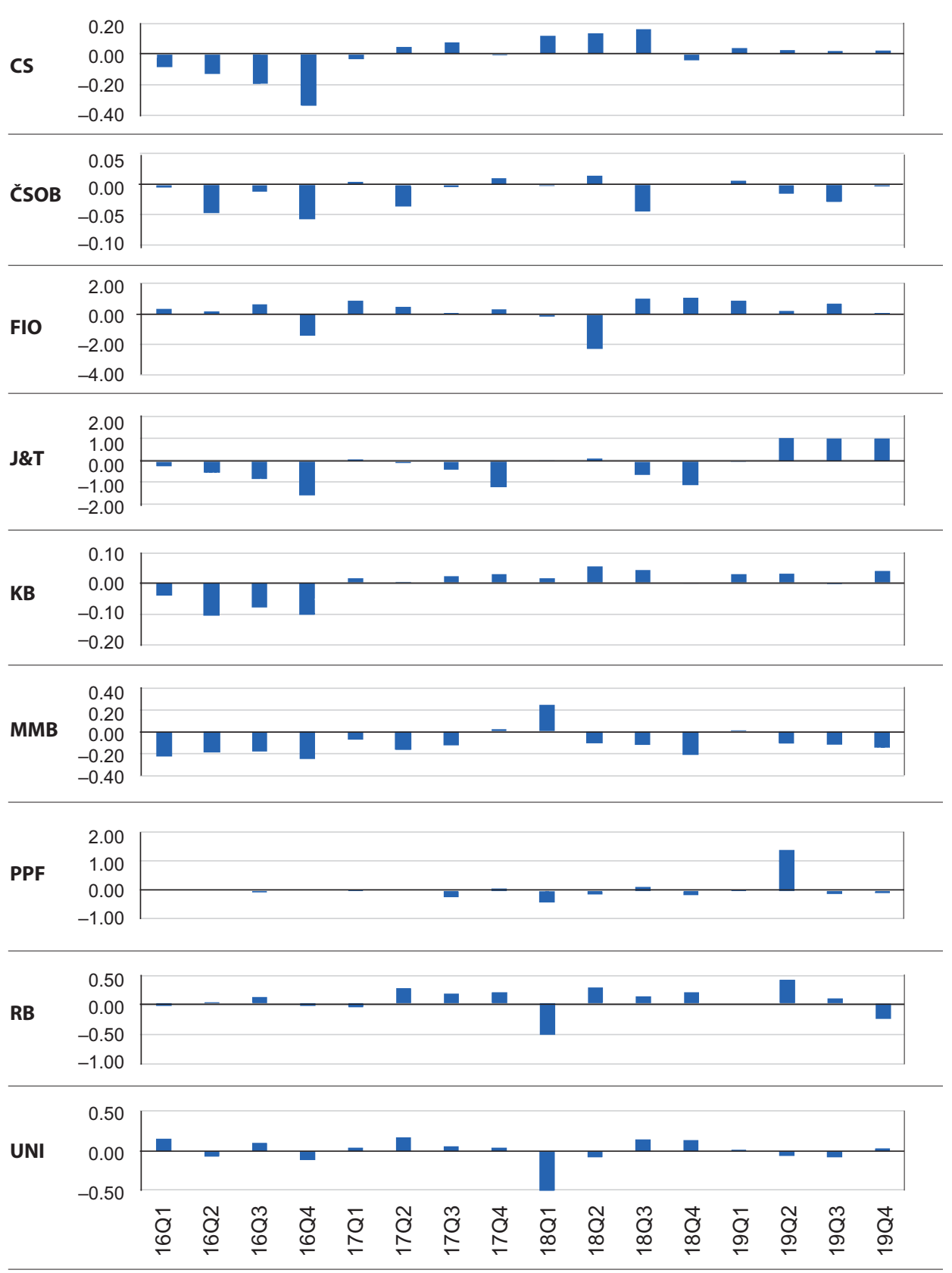

Source: Authors' calculation, data extracted from banks' quarterly reporting 


\section{Figure 3: Quarterly costs of risk in 2016-2019 for whole sample (\%)}

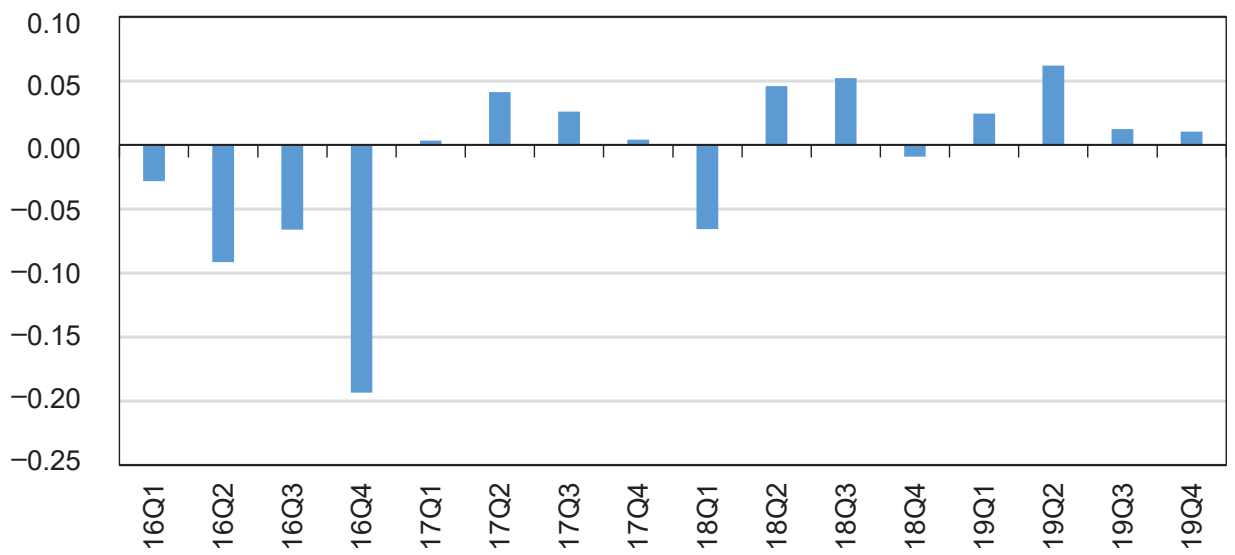

Source: Authors' calculation, data extracted from banks quarterly reporting

To test the hypothesis statistically, we applied the F-test of equality of variances (see Table 6) to the quarterly cost of risk prior to (2016-2017) versus after (2018-2019) the implementation of IFRS 9 at the level of individual banks (i.e., $8+8$ observations for each bank), for the total cost of risk across the sample of banks ( $8+8$ observations, "Total"), and for all the individual cost of risk observations prior to and after IFRS 9 (i.e., $72+72$ observations, "All observations").

Since the tests assume independence of observations, we also tested for serial autocorrelation, which turned out to be significant (at the 5\% level) only for CS and KB in the first lag (see Table 6). The two series were decorrelated (by calculating AR (1) residuals) and the tests were applied to the residuals ( $7+8$ observations). In the case of observations across all the banks, in order to test for a common serial correlation, we applied a panel regression with random effects at the bank and quarterly level. Since the correlation coefficient again turned out significant, we applied the tests to the original panel of observations demeaned at the level of the individual banks to filter out differences in impairment policies and portfolio quality between the banks, and demeaned at quarterly level to filter out systematic time effects.

The results presented in Table 6 show mixed results, but are, overall, in favour of our hypothesis of increased volatility after IFRS 9 adoption. 
Table 6: Volatility of loan loss allowances in 2016-17 versus 2018-19

\begin{tabular}{l|c|c|c|c|c|c|c}
\hline Bank & $\begin{array}{c}\text { Mean } \\
\mathbf{2 0 1 6 - 2 0 1 7} \\
\mathbf{( \% )}\end{array}$ & $\begin{array}{c}\text { St. dev. } \\
\mathbf{2 0 1 6 - 2 0 1 7} \\
\mathbf{( \% )}\end{array}$ & $\begin{array}{c}\text { Mean } \\
\mathbf{2 0 1 8 - 2 0 1 9} \\
\mathbf{( \% )}\end{array}$ & $\begin{array}{c}\text { St. dev. } \\
\mathbf{2 0 1 8 - 2 0 1 9} \\
\mathbf{( \% )}\end{array}$ & $\begin{array}{c}\text { AR (1) } \\
\text { coeff. }\end{array}$ & $\begin{array}{c}\text { F test } \\
\boldsymbol{p} \text {-value }\end{array}$ & $\begin{array}{c}\text { Lev. test } \\
\boldsymbol{p} \text {-val. }\end{array}$ \\
\hline CS & -0.08 & 0.14 & 0.06 & 0.07 & $0.589^{* *}$ & 0.894 & 0.143 \\
\hline CSOB & -0.02 & 0.02 & -0.01 & 0.02 & -0.307 & 0.753 & 0.241 \\
\hline FIO & 0.20 & 0.68 & 0.19 & 1.08 & -0.134 & 0.126 & 0.378 \\
\hline J\&T & -0.54 & 0.53 & 0.20 & 0.75 & $0.539^{*}$ & 0.181 & 0.106 \\
\hline KB & -0.03 & 0.06 & 0.02 & 0.02 & $0.641^{* *}$ & $0.941+$ & 0.248 \\
\hline MMB & -0.14 & 0.08 & -0.14 & 0.13 & 0.236 & 0.115 & 0.406 \\
\hline PPF & 0.02 & 0.09 & -0.07 & 0.54 & -0.063 & $0.000^{* * *}$ & $0.081^{*}$ \\
\hline RB & 0.07 & 0.12 & -0.26 & 0.30 & -0.297 & $0.013^{* *}$ & $0.092^{*}$ \\
\hline UNI & 0.05 & 0.09 & 0.03 & 0.18 & 0.040 & $0.039^{* *}$ & 0.328 \\
\hline Total & -0.04 & 0.08 & -0.04 & 0.04 & 0.326 & $0.942+$ & 0.125 \\
\hline All obser- & - & 0.28 & - & 0.46 & 0.141 & $0.000^{* * *}$ & $0.010^{* *}$ \\
\hline
\end{tabular}

Note: statistical significance indicated by ${ }^{*}, *^{*}, *^{*} p$-values for $10 \%, 5 \%$, and $1 \%$ significance levels, boldfaced values indicate a significant increase in variance after IFRS 9 implementation; for the lower one-tail F-test $\left(\mathrm{HO}\right.$ : variance of IFRS = variance IAS allowances, alternative hypothesis $\mathrm{H}_{\mathrm{a}}$ : variance of IAS < variance IFRS allowances),,++++++ indicate $10 \%, 5 \%$, and $1 \%$ significance levels of the complementary upper one-tail F-test (alternative hypothesis $\mathrm{H}_{\mathrm{a}}$ : variance of IFRS < variance IAS allowances). Source: Authors' calculation

The volatility measured by the standard deviation of the quarterly costs of risk before and after IFRS 9 adoption increased for six out of the nine banks, and in the case of PPF, RB and UNI, the lower one-tail F-test (where the alternative hypothesis states that the variance in the IFRS 9 period is larger than in the IAS 39 period) indicates that the increase is significant, with potential limitations due to data availability and use of a proxy for those banks. On the other hand, the volatility decreased for three banks, with a weakly significant difference only in the case of KB. This is indicated by the complementary upper one-tail F-test (where the alternative hypothesis states the variance in the IAS 39 period is smaller than in the IFRS period). The volatility of the total cost of risk over the sample of banks (where opposite movements might diversify away between the banks) surprisingly decreased from $0.08 \%$ to $0.04 \%$, with the upper one-tail F-test statistic being slightly significant. However, testing the difference between the demeaned cost of risk for all 
observations $(72+72)$ before and after IFRS 9 adoption, the F-test confirms a strongly significant increase in the volatility of allowances. Since the F-test is known to be sensitive to non-normality, and the Jarque-Bera test rejects normality for most of the tested sets of observations (with the exception of CS data), we also applied the two-sided test of Levene (1960), where the null hypothesis states that the variances in the IAS and IFRS period are equal, as a more robust alternative with similar conclusions (see Table 6). According to Levene's test, the variances are not significantly different in any of the cases where the standard deviation in the IFRS 9 period declined, and, on the other hand the increase is still significant in the case of PPF, RB, and on the set of all observations.

\section{Conclusion}

The new IFRS 9 accounting standard became effective at the beginning of 2018. Its main purpose is to change the classification of the impairment of financial assets from realized credit losses to expected credit losses. The implementation of the new standard has been one of the major challenges for all Czech banks in recent years. The aim of this study is to provide an overview of the basic IFRS 9 principles and to identify the main qualitative and quantitative factors that impacted on the Czech banking sector. The new standard is expected be less procyclical compared to IAS 39, but it also brings some negatives, such as the complexity of the new methodology and the potential issue of the volatility of allowances.

The study identified the following qualitative factors Czech banks had to cope with prior to the implementation of the standard and during the first years of its adoption: the necessity of a model for the calculation of ECL, new categorization of receivables, assessment of a significant increase in credit risk and default of receivables, use of forward-looking information in the model for the calculation of ECL and regular validation of this model. The Czech banking sector coped with all these requirements well, mostly by developing a model internally (or within the group), adopting the categorization of receivables into three stages and into subgroups of performing and non-performing exposures, adopting rules for recognition of loan loss allowances on an individual or portfolio basis according to the categorization of receivables, implementing criteria for the assessment of significant increase in credit risk and default and for regular validation of the model.

As a representative of the banking sector in the Czech Republic, a sample of the 9 biggest banks was selected based on a balance sheet volume above 140 billion CZK as of the end of 2019. The hypothesis was stated as follows: The implementation of IFRS 9 increases the volatility of loan loss allowances with an immediate impact on bank results. Quarterly data on the cost of risk and loan receivables of banks in the period 2016-2019 
were used for testing the hypothesis. The standard deviation of relative changes in cost of risk to loan receivables was calculated separately for 2016-2017 and 2018-2019, i.e., for the periods prior to and after IFRS 9 adoption. The standard deviation of the costs of risk observed for all the banks (adjusted for the means at the level of the individual banks and quarters) in 2018-2019 was significantly larger compared to the period 2016-2017 prior to IFRS 9 implementation using the F-test or the alternative Levene's test. For individual banks, the standard deviation in 2018-2019 was higher in the majority of cases - the change was significant at the 5\% significance level using the F-test in three cases, and at the $10 \%$ level using Levene's test in two cases only. Thus, two years after the adoption of the new standard, the hypothesis that implementation of IFRS 9 increases the volatility of loan loss allowances was partially confirmed, even though there are some possible limitations due to data availability and short time series for the IFRS 9 period. However, an examination of the individual allowance flows indicates that the banks are in a process of accommodating and fine-tuning the IFRS 9 models, where, for example, in some cases large initial creation of allowances is followed by relatively unusual releases of allowances in several subsequent quarters. Hence, to fully confirm (or reject) the hypothesis of this article, a new empirical study should be conducted when more data observations are available.

\section{References}

Amel-Zadeh, A., Barth, M. E., Landsman, W. R. (2017). The Contribution of Bank Regulation and Fair Value Accounting to Procyclical Leverage. Review of Accounting Studies, 22(3), 1423-1454, https://doi.org/10.1007/s11142-017-9410-6

BCBS (2015). Guidance on Accounting for Expected Credit Losses. Basel: Bank for International Settlements. Available at: https://www.bis.org/bcbs/publ/d311.pdf

Beatty, A., Liao, S. (2011). Do Delays in Expected Loss Recognition Affect Banks'Willingness to Lend? Journal of Accounting and Economics, 52(1), 1-20, https://doi.org/10.1016/j. jacceco.2011.02.002

Beerbaum, D. (2015). Significant Increase in Credit Risk According to IFRS 9: Implications for Financial Institutions. International Journal of Economics \& Management Sciences, 04(09), 1-3, https://doi.org/10.4172/2162-6359.1000287

Bikker, J., Metzemakers, P. (2005). Bank Provisioning Behaviour and Procyclicality. Journal of International Financial Markets, Institutions and Money, 15(2), 141-157, https://doi.org/10.1016/j.intfin.2004.03.004

Bischof, J., Daske, H. (2016). Interpreting the European Union's IFRS Endorsement Criteria: The Case of IFRS 9. Accounting in Europe, 13(2), 129-168, https://doi.org/10.1080/174494 80.2016.1210181 
Česká spořitelna (2020). Dokumenty ke stažení. [Retrieved 2020-06-02]Available at: https://www.csas.cz/cs/dokumenty-ke-stazeni

ČNB (2014). Č. 163/2014 Sb.: Vyhláška o výkonu činnosti bank, spořitelních a úvěrních družstev a obchodníků s cennými papíry.

ČNB (2020). ARAD Systém časových řad. Praha: ČNB. [Retrieved 2020-06-02] Available at: https://www.cnb.cz/cnb/STAT.ARADY_PKG.PARAMETRY_SESTAVY?p_ sestuid=33051\&p_strid=BAB\&p_lang=CS

ČNB (2020). Banky a pobočky zahraničních bank. Praha: ČNB. [Retrieved 2020-06-02] Available at: https://apl.cnb.cz/apljerrsdad/jerrs.web33. subjects_counts_detail?p_lang=cz\&p_datum=31.12.2018\&p_ses_idx=1

ČSOB (2020). Povinně uveřejňované informace. Praha: ČSOB. [Retrieved 2020-06-02] Available at: https://www.csob.cz/portal/csob/povinne-uverejnovane-informace

FIO Banka (2020). Výsledky hospodaření. Praha: FIO Banka. [Retrieved 2020-06-02] Available at: https://www.fio.cz/o-nas/fio-banka/hospodarske-vysledky

IASB (2003). International Accounting Standard 39 Financial Instruments: Recognition and Measurement. London: International Accounting Standards Board.

IASB (2014). IFRS 9 Financial Instruments. London: International Accounting Standards Board. IFRS Foundation (2014). IFRS 9, Project Summary. London: IFRS Foundation.

J\&T Banka (2020). Informační povinnost. Praha: J\&T Banka. [Retrieved 2020-06-02] Available at: https://www.jtbank.cz/informacni-povinnost

Komerční banka (2020). Pro investory. Praha: Komerční banka [Retrieved 2020-06-02] Available at: https://www.kb.cz/cs/o-bance/pro-investory-rozcestnik

Laeven, L., Majnoni, G. (2003). Loan Loss Provisioning and Economic Slowdowns: Too Much, Too Late? Journal of Financial Intermediation, 12(2), 178-197, https://doi.org/10.1016/ s1042-9573(03)00016-0

Levene, H. (1960). Robust Tests for Equality of Variances, in Olkin, I., et al., eds., Contributions to Probability and Statistics: Essays in Honor of Harold Hotelling. Palo Alto: Stanford University Press, pp. 278-292.

Lukeš, J. (2019). Analýza dopadů IFRS 9 na bankovní sektor v České republice. Český finanční a účetní časopis, 14(3), 17-31, https://doi.org/10.18267/j.cfuc.533

Miu, P., Ozdemir, B. (2017). Adapting the Basel II Advanced Internal Ratings- based Models for International Financial Reporting Standard 9. The Journal of Credit Risk, 13(2), 53-83, https://doi.org/10.21314/jcr.2017.224

MONETA Money Bank (2020). Hospodářské výsledky. Praha: MONETA Money Bank [Retrieved 2020-06-02] Available at: https://investors.moneta.cz/financni-vysledky

Polák, P., Panoš, J. (2019). The Impact of Expectations on IFRS 9 Loan Loss Provisions.

Prague: Czech National Bank. ČNB Research and Policy Notes No. 3/2019. Available at: https://www.cnb.cz/export/sites/cnb/en/economic-research/.galleries/research_ publications/irpn/download/rpn_3_2019.pdf 
Poole, V., Spooner, A., Barden, P., et al. (2016). IGAAP 2016nVolume B Financial Instruments IFRS 9 and related Standards. London, UK: Wolters Kluwer.

PPF banka (2020). Důležité dokumenty. Praha: PPF banka. [Retrieved 2020-06-02] Available at: https://www.ppfbanka.cz/cs/dulezite-dokumenty

Raiffeisen bank (2020). Výsledky hospodaření: Raiffeisenbank. Raiffeisen bank [Retrieved 2020-06-02] Available at: https://www.rb.cz/o-nas/kdo-jsme/vysledky- hospodareni

UniCredit Bank (2020). Povinné údaje o bance: UniCredit Bank. UniCredit Bank [Retrieved 2020-06-02] Available at: https://www.unicreditbank.cz/cs/o-bance/vysledky/povinneudaje-o-bance.html

Witzany, J. (2017). Credit Risk Management: Pricing, Measurement, and Modeling. Cham: Springer. ISBN 978-3-319-49799-0. 